\title{
Increasing and decreasing trends of the atmospheric deposition of organochlorine compounds in European remote areas during the last decade
}

\author{
L. Arellano ${ }^{1}$, P. Fernández ${ }^{1}$, R. Fonts ${ }^{1}$, N. L. Rose $^{2}$, U. Nickus ${ }^{3}$, H. Thies ${ }^{4}$, E. Stuchlík ${ }^{5}$, L. Camarero ${ }^{6}$, J. Catalan ${ }^{7}$, \\ and J. O. Grimalt ${ }^{1}$ \\ ${ }^{1}$ Institute of Environmental Assessment and Water Research (IDÆA-CSIC), Jordi Girona 18. 08034-Barcelona, \\ Catalonia, Spain \\ ${ }^{2}$ Environmental Change Research Centre, University College London, Gower Street, London, WC1E 6BT, United Kingdom \\ ${ }^{3}$ Institute of Meteorology and Geophysics, University of Innsbruck, Innrain 52, Innsbruck, Austria \\ ${ }^{4}$ Institute of Zoology and Limnology, University of Innsbruck, Technikerstrasse 25, 6020 Innsbruck, Austria \\ ${ }^{5}$ Hydrobiological Station, Institute for Environmental Studies, Faculty of Science, Charles University in Prague, \\ P.O. Box 47, 38801 Blatna, Czech Republic \\ ${ }^{6}$ Centre for Advanced Studies of Blanes (CEAB-CSIC), Accés a la Cala St. Francesc 14, 17300-Blanes, Catalonia, Spain \\ ${ }^{7}$ Centre for Ecological Research and Forestry Applications (CREAF), Campus UAB, Edifici C, 08193-Cerdanyola, \\ Catalonia, Spain
}

Correspondence to: P. Fernández (pilar.fernandez@ cid.csic.es)

Received: 3 November 2014 - Published in Atmos. Chem. Phys. Discuss.: 6 February 2015

Revised: 12 May 2015 - Accepted: 15 May 2015 - Published: 4 June 2015

\begin{abstract}
Bulk atmospheric deposition samples were collected between 2004 and 2007 at four high-altitude European sites encompassing east (Skalnaté Pleso), west (Lochnagar), central (Gossenköllesee) and south (Redòn) regions, and analysed for legacy and current-use organochlorine compounds (OCs). Polychlorobiphenyls (PCBs) generally showed the highest deposition fluxes in the four sites, between 112 and $488 \mathrm{ng} \mathrm{m}^{-2} \mathrm{mo}^{-1}$, and hexachlorobenzene (HCB) the lowest, a few $\mathrm{ng} \mathrm{m}^{-2} \mathrm{mo}^{-1}$. Among pesticides, endosulfans were found at higher deposition fluxes (11$177 \mathrm{ng} \mathrm{m}^{-2} \mathrm{mo}^{-1}$ ) than hexachlorocyclohexanes (HCHs) (17-66 $\mathrm{ng} \mathrm{m}^{-2} \mathrm{mo}^{-1}$ ) in all sites except Lochnagar that was characterized by very low fluxes of this insecticide.

Comparison of the present measurements with previous determinations in Redòn (1997-1998 and 2001-2002) and Gossenköllesee (1996-1998) provided for the first time an assessment of the long-term temporal trends in OC atmospheric deposition in the European background areas. PCBs showed increasing deposition trends while HCB deposition fluxes remained nearly constant. Re-emission of PCBs from soils or as a consequence of glacier melting and subsequent precipitation and trapping of the volatilized compounds may
\end{abstract}

explain the observed PCB trends. This process does not occur for HCB due to its high volatility which keeps most of this pollutant in the gas phase.

A significant decline of pesticide deposition was observed during this studied decade (1996-2006) which is consistent with the restriction in the use of these compounds in most of the European countries. In any case, degassing of HCHs or endosulfans from ice melting to the atmosphere should be limited because of the low Henry's law constants of these compounds that will retain them dissolved in the melted water.

Investigation of the relationship between air mass trajectories arriving at each site and $\mathrm{OC}$ deposition fluxes showed no correlation for PCBs, which is consistent with diffuse pollution from unspecific sources as the predominant origin of these compounds in these remote sites. In contrast, significant correlations between current-use pesticides and air masses flowing from the south were observed in Gossenköllesee, Lochnagar and Redòn. In the case of Redòn, the higher proportion of air masses from the south occurred in parallel to higher temperatures, which did not allow us to discriminate between these two determinant factors of pesti- 
cide deposition. However, in Gossenköllesee and Lochnagar, the relationship between pesticide concentration and southern air masses was univocal, reflecting the impact of regions with intensive agricultural activities.

\section{Introduction}

The persistent organic pollutants (POPs) encompass a group of organic compounds, such as polychlorobiphenyls (PCBs), hexachlorobenzene $(\mathrm{HCB})$ and others that were banned in many countries during the 1970s and the 1980s because of their persistence, toxicity, long-range transport potential and food-web bioaccumulation (UNEP, 2001).

Anthropogenic activities are very limited in high mountain regions which therefore constitute the most pristine ecosystems in the continents. However, there is evidence that even these areas receive impacts of long-range atmospheric transported pollutants such as POPs (Blais et al., 1998; Wang et al., 2009; Estellano et al., 2008; Fernández and Grimalt, 2003; Fernández et al., 1999; Daly and Wania, 2005). As observed in the polar regions (Cabrerizo et al., 2012; Halsall, 2004), field studies in Europe (Grimalt et al., 2001), western Canada (Davidson et al., 2003), South America (Grimalt et al., 2004a; Pozo et al., 2007) and the Tibetan Plateau (Liu et al., 2010) among others, have shown that mountains can act as cold-traps for POPs or even organic compounds with limited atmospheric transport, e.g. currently used pesticides (Hageman et al., 2006). These previous studies have documented the overall accumulation process but the mechanisms by which these compounds are transported through the atmosphere and accumulate in these environments are largely unknown.

Atmospheric deposition is the main pathway by which POPs are incorporated into pristine regions (Carrera et al., 2002; Fernández et al., 2003). Unfortunately, there are substantial gaps of knowledge concerning the specific transfer mechanisms occurring at these sites, such as the influence of the physical-chemical properties of the trapped compounds and the environmental factors that are relevant for the overall deposition efficiencies.

These aspects are relevant in the context of the regulatory measures for POP synthesis and use that have led to declines in the concentrations of these compounds in several environments (Brun et al., 2008; Holoubek et al., 2007). As atmospheric concentrations of POPs decrease following restrictions on their emissions from primary sources, revolatilization from terrestrial surfaces of previously deposited pollutants, e.g. secondary sources, becomes an important component of their global environmental cycling (Nizzetto et al., 2010; Li et al., 2010). These processes may be particularly significant in remote cold regions, since POPs accumulated in soils and snow/ice surfaces of these areas in the past (Grimalt et al., 2001, 2004b, 2009; Guazzoni et al., 2011). In- deed, recent studies have provided evidence that revolatilization has already begun in polar (Ma et al., 2011; Wong et al., 2011) and Alpine regions (Bogdal et al., 2009).

Full understanding of these aspects is important because the remote mountain regions are the areas of most pristine freshwater formation. The pollutants incorporated in the waters of these ecosystems define a quality ceiling from which water properties will decrease upon transport to lower altitudes, e.g. as consequence of the incorporation of more pollutants.

In order to gain insight into these questions, POP concentrations were determined in bulk atmospheric deposition samples collected monthly in four mountain areas distributed throughout Europe between 2004 and 2006. The sampling sites encompassed the south (Pyrenees), central (Alps), east (Tatras), and west Europe (Grampians). In each site, every 2 days during the sampling period, backwards air mass trajectories were calculated to reconstruct the last $72 \mathrm{~h}$ air mass locations at $6 \mathrm{~h}$ intervals (Arellano et al., 2014).

The POPs analysed included both legacy, PCBs, HCB and hexachlorocyclohexanes (HCHs), and current-use compounds, endosulfans. The specific objectives of this study are: (i) to determine the current levels of organochlorine compounds (OCs) in bulk deposition samples from remote areas of Europe representing different climatic regions; (ii) to investigate seasonal, spatial and temporal trends in the atmospheric deposition of OCs in these areas; (iii) to determine which environmental variables control the atmospheric deposition fluxes of OCs and to quantify their influence, and (iv) to identify potential source regions of these compounds in high mountain areas of Europe.

\section{Materials and methods}

\subsection{Chemicals}

Isooctane, $n$-hexane, dichloromethane, cyclohexane, methanol and acetone were used for trace analysis (Merck; Darmstadt, Germany). Anhydrous sodium sulfate (analytical-reagent grade, Merck) and aluminium oxide were cleaned by Soxhlet extraction with dichloromethane:hexane $(1: 1, v / v, 24 \mathrm{~h})$ and before use they were activated by overnight heating at 450 and $120^{\circ} \mathrm{C}$, respectively.

Glass fibre filters $(47 \mathrm{~mm}$ diameter, $1 \mathrm{~mm}, \mathrm{GF} / \mathrm{B}$, Whatman, Maidstone, UK) were kiln-fired at $400^{\circ} \mathrm{C}$ for $12 \mathrm{~h}$, weighted and wrapped into aluminium foil until use. Empore $\mathrm{C}_{18}$ extraction discs $(47 \mathrm{~mm}$ diameter, $0.5 \mathrm{~mm}$ thickness) were from $3 \mathrm{M}$ Co. (St Paul, MN, USA).

PCB 142 (internal standard), PCB 30 and PCB 209 (recovery standards) and a standard solution of HCHs, PCBs, $\mathrm{HCB}$ and endosulfans were purchased from Dr Ehrenstorfer (Augsburg, Germany). 


\subsection{Sampling}

Bulk (dry and wet) atmospheric deposition samples were regularly collected at the four remote high mountain areas selected for study (Table 1) over different time periods: monthly (one sample for the whole month deposition) from 2004 to 2006 in Gossenköllesee, Lake Redòn and Skalnaté Pleso and biweekly (one sample for the whole 2-week deposition) from 2004 to 2007 in Lochnagar. Further information concerning sampling devices and conditions is reported in Arellano et al. (2014).

Samples were filtered on site using pre-weighed glass fibre filters. The filtrates were solid-phase extracted with $\mathrm{C}_{18}$ discs as described in Carrera et al. (1998). After sample removal, the bulk collectors were rinsed with Milli-Q water which was filtered, solid-phase extracted, and the extracts combined with those of the corresponding atmospheric deposition sample. Glass fibre filters and discs were wrapped in aluminium foil and transported frozen to the laboratory. Meteorological parameters, namely air temperature and precipitation, were provided by automatic weather stations (AWS) located at each site.

\subsection{Extraction and clean-up}

Glass-fibre filters were freeze-dried and weighed for measuring total particle content in bulk atmospheric deposition samples. OCs were extracted from the filters by sonication with dichloromethane : methanol $(2: 1)(3 \times 10 \mathrm{~mL}, 20 \mathrm{~min}$ each). Pollutants adsorbed in the $\mathrm{C}_{18}$ discs were eluted sequentially with methanol, cyclohexane and dichloromethane (Carrera et al., 1998). Both filter extracts and $\mathrm{C}_{18}$ disc eluates were combined and purified by column adsorption chromatography with aluminium oxide after adding a recovery standard mixture of PCB 30 and PCB 209. Prior to instrumental analysis, samples were spiked with PCB 142 as internal standard.

\subsection{Instrumental analysis}

PCBs, HCB and HCHs were analysed by gas chromatography with micro-electron capture detector $(\mathrm{GC}-\mu \mathrm{ECD})$ (Agilent Technologies $6890 \mathrm{~N}$ ). The chromatographic conditions are reported in detail elsewhere (Carrera et al., 1998). Endosulfans ( $\alpha$ - and $\beta$-isomers and endosulfan sulfate) were analysed by gas chromatography coupled to mass spectrometry in negative ion chemical ionization (GC-MS-NICI) and selective ion recording modes (Trace DSQ Instrument Thermo Electron). This technique was also used for structural confirmation of all OCs.

For the GC-MS-NICI determinations, extracts were injected in a HP-5MS capillary column $(30 \mathrm{~m}$ long, $0.25 \mathrm{~mm}$ internal diameter and $0.25 \mu \mathrm{m}$ film thickness). Helium was used as carrier gas $\left(1.2 \mathrm{~mL} \mathrm{~min}^{-1}\right)$ and ammonia as reagent gas $\left(2.5 \mathrm{~mL} \mathrm{~min}^{-1}\right)$. The oven temperature programme encompassed an initial temperature of $90^{\circ} \mathrm{C}$, which was held for $1 \mathrm{~min}$, followed by a first increase to $130^{\circ} \mathrm{C}$ at $8^{\circ} \mathrm{C} \mathrm{min}-1$ and a final ramp to $325^{\circ} \mathrm{C}$ at $5^{\circ} \mathrm{C} \mathrm{min}{ }^{-1}$ with a hold time of $10 \mathrm{~min}$. Injector, transfer line and ion source temperatures were 270,280 and $176^{\circ} \mathrm{C}$, respectively. The ions selected for compound identification and quantitation were $m / z 406$ (quantification), $m / z 372$ and $m / z 161$ for $\alpha$ - and $\beta$ endosulfan, and $m / z 386$ (quantification), $m / z 372$ and $m / z$ 161 for endosulfan sulfate.

This technique was also used for quantification of the other OCs when the interferences in GC- $\mu$ ECD did not allow their determination.

\subsection{Quality control and assurance}

Quantification was performed by the internal standard method. Field and procedural blanks were obtained at each sampling site and processed together with the samples. For field blanks, Milli-Q water was filtered, solid-phase adsorbed, transported and stored for subsequent analysis in parallel to real samples. In general, blank values represent less than $10 \%$ of bulk deposition sample concentrations. These values were used to determine method detection limits (MDL) that were established as the average blank value plus 3 times the standard deviation. MDL for PCBs ranged between 0.17 and $1.6 \mathrm{ng}$ depending on the congener examined, $0.20 \mathrm{ng}$ for $\mathrm{HCHs}, 0.04 \mathrm{ng}$ for $\mathrm{HCB}$, and between 0.05 and $0.10 \mathrm{ng}$ for the endosulfans. Efficiency of the analytical procedure was evaluated from recoveries of the surrogate standards, which varied between $51 \pm 18 \%$ for PCB 30 and $85 \pm 25 \%$ for PCB 209. All reported values were recovery corrected.

\section{Results}

\subsection{OC deposition fluxes and spatial distribution}

Atmospheric deposition fluxes $\left(\mathrm{ng} \mathrm{m}^{-2} \mathrm{mo}^{-1}\right)$ were calculated by multiplying the $\mathrm{OC}$ concentrations $\left(\mathrm{ng} \mathrm{L}^{-1}\right)$ measured in each sample by the collected volume and dividing by the surface area of the collection funnel and the sampling time, around 1 month for most of the samples. In Lochnagar, where each sample corresponded to 2 weeks, monthly deposition was obtained by summing the values of two consecutive samples. For sampling times higher than 1 month, a correction factor was applied in order to normalize all values at monthly basis. The mean deposition fluxes of HCHs $(\alpha-$ and $\gamma-\mathrm{HCH}), \mathrm{HCB}$, endosulfans ( $\alpha$ - and $\beta$-endosulfan, and endosulfan sulfate), and PCBs (sum of PCB 28, 52, 101, $118,153,138$, and 180) to each study site are summarized in Table 2. All studied compounds were found in the four sampling sites, with detection frequencies higher than $80 \%$, except for PCB 28 in Redòn (detected in $65 \%$ of the samples) and $\alpha$ - and $\beta$-endosulfans in Lochnagar (frequency of detection 61 and $68 \%$, respectively). 


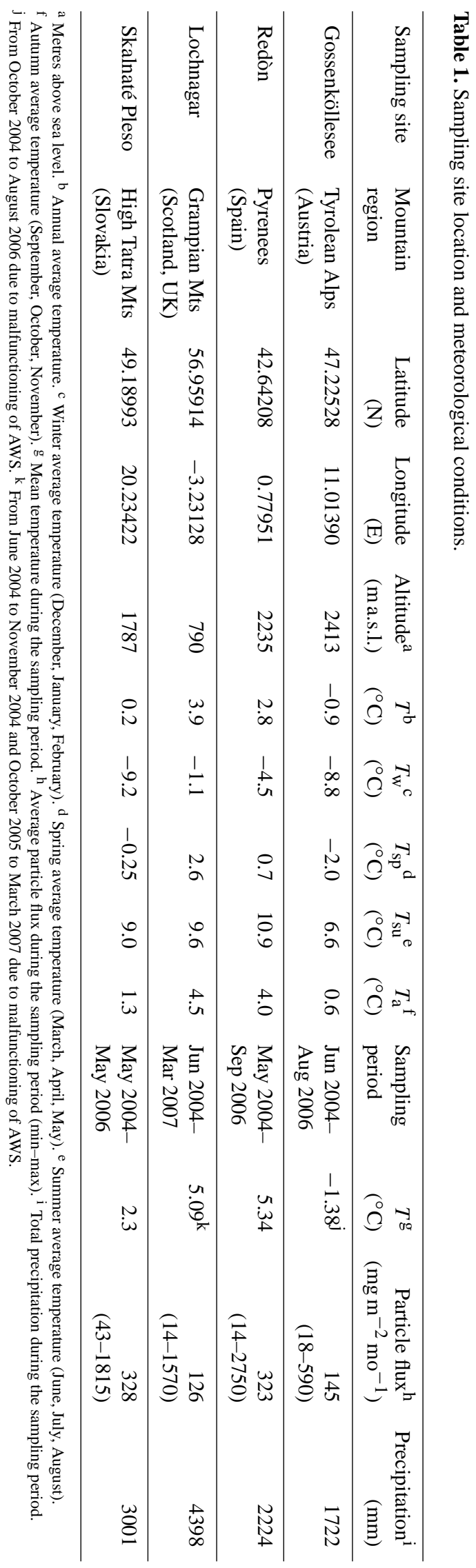


Table 2. Average atmospheric deposition fluxes of organochlorine compounds (min.-max.) in remote European regions (ng $\mathrm{m}^{-2} \mathrm{mo}^{-1}$ ).

\begin{tabular}{lrrrr}
\hline & $\begin{array}{r}\text { Lochnagar } \\
(n=44)\end{array}$ & $\begin{array}{r}\text { Redòn } \\
(n=22)\end{array}$ & $\begin{array}{r}\text { rossenköllesee } \\
(n=18)\end{array}$ & $\begin{array}{r}\text { Skalnaté } \\
(n=24)\end{array}$ \\
\hline$\sum 7$ PCBs & $305(78-876)$ & $112(26-227)$ & $168(22-510)$ & $488(94-2340)$ \\
$\alpha$-HCH & $19(3.2-93)$ & $5.7(1.5-11)$ & $4.6(1.3-15)$ & $16(1.3-53)$ \\
$\gamma$-HCH & $37(6.2-130)$ & $12(1.9-30)$ & $20(3.6-61)$ & $50(3.8-186)$ \\
$\sum$ HCHs & $56(12-199)$ & $17(3.5-38)$ & $25(5.4-71)$ & $66(6.6-238)$ \\
HCB & $3.7(0.55-11)$ & $1.1(0.13-6.5)$ & $1.0(\mathrm{BDL}-8.1)$ & $12(\mathrm{BDL}-86)$ \\
$\alpha$-Endosulfan & $3.3(\mathrm{BDL}-19)$ & $17(\mathrm{BDL}-93)$ & $4.8(\mathrm{BDL}-19)$ & $20(\mathrm{BDL}-119)$ \\
$\beta$-Endosulfan & $2.6(\mathrm{BDL}-16)$ & $47(\mathrm{BDL}-205)$ & $12(\mathrm{BDL}-39)$ & $127(0.35-637)$ \\
Endosulfan sulfate & $5.8(\mathrm{BDL}-25)$ & $26(\mathrm{BDL}-148)$ & $11(0.66-34)$ & $30(0.71-118)$ \\
$\sum$ Endosulfans & $11(\mathrm{BDL}-43)$ & $89(\mathrm{BDL}-446)$ & $28(0.66-77)$ & $177(1.3-832)$ \\
$\alpha / \gamma$-HCH & $0.51(0.0-0.93)$ & $0.50(0.15-2.4)$ & $0.23(0.06-1.1)$ & $0.32(0.05-1.1)$ \\
$\alpha / \beta$-Endosulfans & $2.0(0.0-6.5)$ & $0.76(0.0-4.9)$ & $0.72(0.0-2.4)$ & $0.54(0.05-5.8)$ \\
\hline
\end{tabular}

BDL means below detection limit. $\sum$ PPCBs, sum of PCBs 28, 52, 101, 118, 153, 138 and 180.

The most abundant OC pollutants in all sites were PCBs, with fluxes ranging between $112 \mathrm{ng} \mathrm{m}^{-2} \mathrm{mo}^{-1}$ (Redòn) and $488 \mathrm{ng} \mathrm{m}^{-2} \mathrm{mo}^{-1}$ (Skalnaté). In contrast, $\mathrm{HCB}$ exhibited the lowest deposition, generally in the range of a few

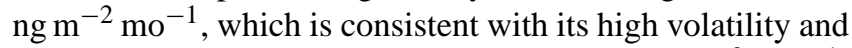
Henry's law constant $\left(P_{L}=0.094 \mathrm{~Pa} ; H=65 \mathrm{~Pa} \mathrm{~m}^{3} \mathrm{~mol}^{-1}\right.$, Shen and Wania, 2005), which inhibit its removal from the atmosphere by any of the deposition mechanisms (airwater exchange or dry and wet deposition). Among pesticides, endosulfans were found at higher concentrations (11$177 \mathrm{ng} \mathrm{m}^{-2} \mathrm{mo}^{-1}$ ) than HCHs (17-66 $\mathrm{ng} \mathrm{m}^{-2} \mathrm{mo}^{-1}$ ) in all sites except Lochnagar, where endosulfans were found at very low concentrations. This difference likely reflects the phasing out of HCHs in the European countries.

Skalnaté Pleso exhibited the highest deposition fluxes of all studied OCs, generally followed by Lochnagar (Table 2). The lowest levels of legacy OCs ( $\alpha$ - and $\gamma-\mathrm{HCH}, \mathrm{HCB}$ and PCBs) were found in Redòn. However, significant amounts of endosulfans (pesticides of current use) were observed in this site, which is in agreement with the influence of agricultural activities in the south of Europe. The higher concentrations of OCs, especially PCBs, in east Europe are consistent with the high historical use and production of these compounds in central Europe and the former Czechoslovakia until 1984 (Taniyasu et al., 2003; Holoubek et al., 2007). Similar spatial distribution of PCBs and $\mathrm{HCHs}$ in remote European air samples was observed elsewhere (Halse et al., 2011), with higher concentrations in east Europe and lower in the Iberian Peninsula, which was attributed to the prevailing wind regimes from west to east. Nevertheless, these authors also found low levels of these compounds in the atmosphere over the British Isles, which is not observed in the present study.

The differences between sites for the legacy compounds are low, within a factor of 4 at the most. The present fluxes of these compounds probably reflect emissions to the Eu- ropean atmosphere originating from secondary sources, e.g. soils. HCB exhibited a different spatial pattern with similar fluxes in Lochnagar, Redòn and Gossenköllesee, and 1 order of magnitude higher in Skalnaté. The high volatility and atmospheric mobility of this compound has resulted in rather uniform air concentrations in remote areas (Jaward et al., 2004). In contrast, the spatial pattern observed in the present study suggests that there are emission sources of this pollutant near the Tatra Mts, likely as a consequence of the production of organochlorinated solvents or application of HCB-contaminated pesticides, e.g. chlorothalonil (Hung et al., 2010).

Conversely, the endosulfans exhibit higher deposition fluxes in Redòn and Skalnaté, with differences between sites above 1 order of magnitude. These results are consistent with primary sources of this pesticide related to agriculture in southern and eastern Europe.

The PCB deposition fluxes found in Redòn and Gossenköllesee are in the range of those reported in remote or background sites such as the Baltic Sea, NE Atlantic, and eastern Mediterranean region (Table 3). In contrast, the higher fluxes in Lochnagar and Skalnaté are similar to those measured in urban areas of Chicago or Texas (Table 3). This unexpected result could reflect the influence of post-PCB uses near these deposition sites, as described for HCB in Skalnaté. However, most of the previous studies on PCB levels in atmospheric deposition focused on wet-only deposition, while the present work also includes dry deposition. In this sense, several authors have stated that particle scavenging was the dominant source of PCBs in rain despite the small fraction of these compounds associated with atmospheric particles (Dickhut and Gustafson, 1995; Poster and Baker, 1996). In addition, a significant fraction of the annual precipitation to these remote mountain sites is in the form of snow, which has been reported to be more efficient than rain for organic pollutant scavenging from the atmosphere (Lei 
Table 3. Comparison of mean deposition fluxes of OC measured in remote European mountain regions with those reported in the literature.

\begin{tabular}{|c|c|c|c|c|c|c|}
\hline Site/compound & Sampling period & $\sum \mathrm{PCBs}$ & $\sum \mathrm{HCHs}$ & Eendo. & $\mathrm{HCB}$ & Reference \\
\hline Redòn $^{\mathrm{a}}$ & Jul 2004-Aug 2006 & 112 & 17 & 89 & 1.1 & This study \\
\hline Gossenköllesee $^{\mathrm{a}}$ & Jun 2004-Aug 2006 & 168 & 25 & 28 & 1.0 & This study \\
\hline Skalnaté Pleso ${ }^{\mathrm{a}}$ & May 2004-May 2006 & 488 & 66 & 177 & 12 & This study \\
\hline Lochnagar $^{\mathrm{a}}$ & Sep 2004-Mar 2007 & 305 & 56 & 11 & 3.7 & This study \\
\hline Eastern Mediterranean (background) & $2000-2001$ & $10-180^{\mathrm{b}}$ & - & - & - & Mandalakis and Stephanou, 2004 \\
\hline New Jersey (background) & $1997-2001$ & $25-30^{c}$ & - & - & - & Totten et al., 2004 \\
\hline New Jersey (urban and suburban) & $1997-2001$ & $330-1320^{\mathrm{c}}$ & - & - & - & Totten et al., 2004 \\
\hline Baltic Sea & 1990-1992 & $36-168^{\mathrm{b}}$ & - & - & - & Agrell et al., 2002 \\
\hline Great Lakes (remote sites) & & $120-270$ & - & - & - & Hillery et al., 1998 \\
\hline NE Atlantic ${ }^{\mathrm{a}}$ (remote) & May 1999-Jul 2000 & $65^{\mathrm{d}}$ & 35 & - & 7.2 & Van Drooge et al., 2001 \\
\hline Natural Reserve, Hong Kong, China ${ }^{a}$ & Aug 2002-Jul 2003 & - & n.d. -3.9 & n.d. $-3.15^{\mathrm{j}}$ & $1.8-20.3$ & Wong et al., 2004 \\
\hline Rio Janeiro, Brazil ${ }^{\mathrm{a}}$ (industrial) & 2003-2004 & $510-9420$ & - & - & - & de Souza et al., 2007 \\
\hline Chicago, USA (urban) & $1997-2003$ & $252^{\mathrm{e}}$ & - & - & - & Sun et al., 2006a \\
\hline Chicago, USA (background) & & $42^{\mathrm{e}}$ & - & - & - & \\
\hline Galveston Bay, Texas (urban) & Feb 1995-Aug 1996 & $128^{\mathrm{c}}$ & $136^{\mathrm{g}}$ & - & 7.5 & Park et al., 2001 \\
\hline Madison (USA) & $1996-1998$ & 217 & - & - & - & Murray and Andren, 1992 \\
\hline Southern Ontario, Canada ${ }^{\mathrm{a}}$ (background) & May-Nov 2002 & $26.5-903$ & - & - & - & Su et al., 2007 \\
\hline Lake Ontario, Canada (rural) & Sept 2002-Oct 2003 & - & $360^{\mathrm{h}}$ & - & - & Blanchard et al., 2006 \\
\hline \multirow[t]{2}{*}{ Atlantic Canada (background) } & $1994-1999$ & - & $112-182^{\mathrm{i}}$ & $65.3-145^{\mathrm{j}}$ & - & Brun et al., 2008 \\
\hline & & - & $54.2-122^{\mathrm{h}}$ & - & - & \\
\hline South Florida, USA (agricultural) & Jan 2003-Mar 2006 & - & - & $6070-6130$ & - & Potter et al., 2014 \\
\hline South Florida, USA (background) & Nov 2002-Aug 2006 & - & - & $49-76$ & - & \\
\hline \multirow[t]{2}{*}{ Flanders, Belgium } & 1997 & - & 1692 & 876 & - & Quaghebeur et al., 2004 \\
\hline & 2001 & - & - & 208 & - & \\
\hline New York-New Jersey & Jan 2000-May 2001 & - & n.d. & $51-127$ & - & Gioia et al., 2005 \\
\hline Chesapeake Bay, USA & Apr-Sep 2000-2004 & - & 93.3 & 382 & - & Goel et al., 2005 \\
\hline Izmir, Turkey (suburban) & Not reported & $401^{\mathrm{f}}$ & 63.3 & 150 & - & Odabasi et al., 2008 \\
\hline
\end{tabular}

Levels from the literature refer to wet-only deposition. "n.d." means not detected. ${ }^{\text {a }}$ Bulk deposition. ${ }^{\mathrm{b}}$ Sum of 54 congeners. ${ }^{\mathrm{c}}$ Sum of more than 90 congeners. ${ }^{\mathrm{d}}$ Sum of 14 congeners. ${ }^{\mathrm{e}}$ Sum of 84 congeners.

${ }^{\mathrm{f}}$ Sum of 9 congeners. ${ }^{\mathrm{g}}$ Sum of $4 \mathrm{HCH}$ isomers. ${ }^{\mathrm{h}}$ Lindane. ${ }^{\mathrm{i}} \alpha$-HCH. ${ }^{\mathrm{j}}$ Sum of $\alpha$ - and $\beta$-endo.

and Wania, 2004; Zhang et al., 2015). Both factors - contribution of dry deposition and snow scavenging efficiency - may explain the relatively high deposition fluxes of PCBs found in Lochnagar and Skalnaté.

For the other studied compounds, the deposition fluxes were low, similar or even lower than the levels reported in remote regions (Table 3).

\subsection{Compound distributions}

\subsubsection{Polychlorobiphenyls}

The congener distributions of these compounds were dominated by the lower molecular weight compounds with PCB 101 and PCB 52 as the most abundant congeners (Fig. 1), except in Redòn where PCB 138 predominates. This congener is also the main PCB of low volatility in all sites. The distributions are rather uniform regardless of location or season (differences not statistically significant at $95 \%$ confidence level, ANOVA).

The congener distribution found in this study is similar to that reported in atmospheric deposition of other sites, with PCB mixtures dominated by congeners containing three to six chlorine atoms (Franz and Eisenreich, 1993; Agrell et al., 2002), but with somewhat higher contribution of less volatile PCBs than in background areas of eastern Mediterranean Sea (Mandalakis and Stephanou, 2004) or in previous measurements on PCB deposition in high-altitude mountain sites of Europe (Carrera et al., 2002). This shift towards more chlorinated PCB predominance could be related to emissions from mountain soils and glaciers which are likely enriched in these congeners as a consequence of their selective accumulation by the cold-trap effect observed in high mountain areas from temperate latitudes (Grimalt et al., 2001; Carrera et al., 2001).

\subsubsection{Hexachlorocyclohexanes}

These insecticides were used in the past as technical mixtures, $\alpha-\mathrm{HCH}, 60-70 \%$ and $\gamma-\mathrm{HCH}, 10-15 \%$, with a $\alpha-$ $\mathrm{HCH} / \gamma-\mathrm{HCH}$ ratio of 4-7 (Jantunen et al., 2008) or lindane, the $\gamma$-isomer $(\geq 99 \%)$. Nowadays, the use of lindane ceased in the majority of the European countries (in France it was banned in 1998, in Germany in 2004) and Canada (Li and Vijgen, 2006; Becker et al., 2008).

In this study, $\gamma-\mathrm{HCH}$ was the major isomer found in the four sampling sites, representing between $66 \%$ of total HCHs (Lochnagar) and $81 \%$ (Gossenköllesee). Consequently, the $\alpha-\mathrm{HCH} / \gamma-\mathrm{HCH}$ ratios, $0.23-0.51$, were far below the values measured in the technical $\mathrm{HCH}$ mixture (47). This result is consistent with the phasing out of technical $\mathrm{HCH}$ in Europe and the subsequent use of lindane. In addition, higher Henry's law constant of $\alpha-\mathrm{HCH}$ than $\gamma$ - 


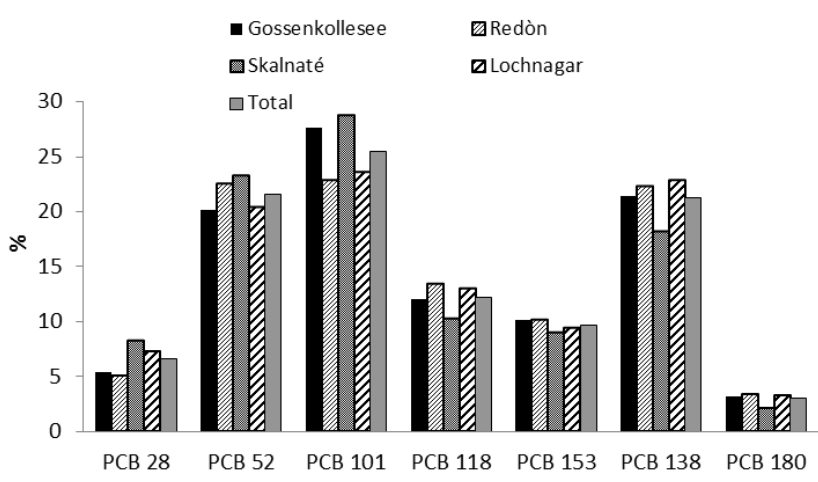

Figure 1. Mean percentage contribution of PCB congeners for all deposition samples (total) and for each study site.

$\mathrm{HCH}$ would enhance the predominant deposition of $\gamma$ over $\alpha$-isomer which will lower the ratio in relation to what is present in the atmosphere. A dominant usage of lindane has been reported in the western part of Europe, while the technical HCH tended to dominate in east Europe (Halse et al., 2011). This geographical difference is not reflected in the atmospheric deposition patterns of this study, since the $\alpha / \gamma$ $\mathrm{HCH}$ ratios were consistently lower in the eastern and central European sites, Gossenköllesee and Skalnaté, than in Lochnagar and Redòn, situated in western Europe (Table 2).

\subsubsection{Endosulfan}

This is a broad-spectrum insecticide of global current use. USA and several countries in Europe have stopped its production which has resulted in declining concentrations in the Northern Hemisphere during the last years (Weber et al., 2010). Since May 2011, it has been included in the list of chemicals banned under the Stockholm Convention with some specific exemptions (http://chm.pops.int/Implementation/NewPOPs/ The9newPOPs/tabid/672/language/en-US/Default.aspx).

The endosulfan isomers in Gossenköllesee, Redòn and Skalnaté Pleso were dominated by $\beta$-endosulfan, with an $\alpha / \beta$ ratio ranging between 0.51 and 0.58 . This composition contrasts with the relative proportion found in the technical mixtures, ratios between 2 and 2.3. Several studies have reported higher concentrations of $\beta$-endosulfan in precipitation than $\alpha$-endosulfan (Brun et al., 2008; Arellano et al., 2011; Sun et al., 2006b; Carrera et al., 2002) despite that concentrations in air followed the relative isomeric proportions of the commercial formulations. The lower Henry's law constant of $\beta$-endosulfan than $\alpha$-endosulfan may result in the preferential deposition of the $\beta$-isomer by dry and wet deposition processes. In addition, higher concentrations of $\beta$-endosulfan have been observed in atmospheric particles (Brun et al., 2008) which may increase the concentrations of this isomer in deposition samples. In Lochnagar, endosulfan sulfate, a breakdown product of both $\alpha$ and $\beta$ isomers, was
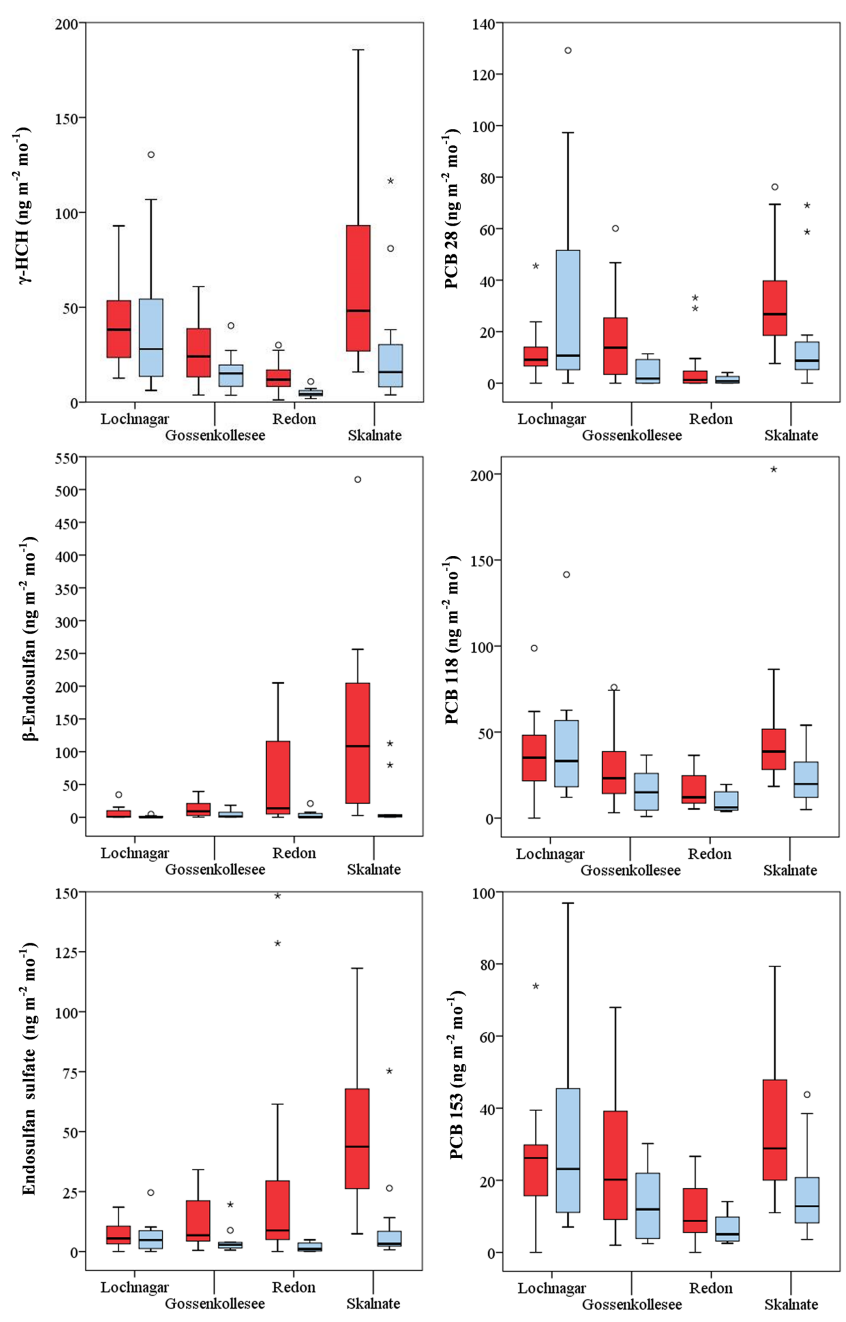

Figure 2. Boxplots of several OC deposition fluxes during warm (red) and cold (blue) seasons at the study sites. Horizontal lines represent the median value. Atypical values (outside 1.5 times the interquartile range, IQR) are indicated by empty dots, while asterisks represent extreme values (outside $3 \times \mathrm{IQR}$ ).

the compound exhibiting highest values and the mean $\alpha / \beta$ ratio was higher than in the other sites, 1.3 , but still lower than the values of the technical mixtures. The dominance of endosulfan sulfate is consistent with the low fluxes of the $\alpha$ and $\beta$-isomers and suggests that the inputs of this insecticide arriving to this site were either from distant sources or very old spills.

\section{Discussion}

\subsection{Influence of meteorological and atmospheric variables in the deposition fluxes of OCs}

Pearson correlation coefficients of the log-transformed OC deposition fluxes and particle concentration, monthly mean 
Table 4. Pearson correlation coefficients of $\mathrm{OC}$ deposition fluxes $\left(\mathrm{ng} \mathrm{m}{ }^{-2} \mathrm{mo}^{-1}, \log\right.$-transformed $)$ and monthly mean temperature $\left(T,{ }^{\circ} \mathrm{C}\right)$, precipitation (Precip, $\left.\mathrm{mm} \mathrm{mo}^{-1}\right)$, and particle deposition $\left(\mathrm{mg} \mathrm{m}^{-2} \mathrm{mo}^{-1}\right.$, log-transformed) for the study sites.

\begin{tabular}{|c|c|c|c|c|c|c|c|c|c|c|c|c|}
\hline & \multicolumn{3}{|c|}{ Redòn } & \multicolumn{3}{|c|}{ Gossenköllesee } & \multicolumn{3}{|c|}{ Skalnaté } & \multicolumn{3}{|c|}{ Lochnagar } \\
\hline & Precip & $T$ & Particles & Precip & $T$ & Particles & Precip & $T$ & Particles & Precip & $T$ & Particles \\
\hline$\alpha-\mathrm{HCH}$ & - & - & - & - & - & - & $0.612^{\mathrm{b}}$ & $0.622^{b}$ & $0.510^{\mathrm{b}}$ & $0.564^{b}$ & - & - \\
\hline$\alpha / \gamma-\mathrm{HCH}$ & - & - & - & - & - & - & - & - & - & $0.373^{\mathrm{a}}$ & - & - \\
\hline$\alpha$-endosulfan & - & - & - & - & - & - & $0.652^{\mathrm{b}}$ & $0.687^{b}$ & $0.698^{\mathrm{b}}$ & $0.526^{\mathrm{a}}$ & $0.543^{\mathrm{a}}$ & - \\
\hline$\beta$-endosulfan & - & $0.515^{\mathrm{a}}$ & - & - & - & - & $0.636^{\mathrm{b}}$ & $0.747^{\mathrm{b}}$ & $0.729^{\mathrm{b}}$ & - & - & - \\
\hline$\sum$ Endosulf & - & $0.660^{b}$ & - & - & - & $0.486^{\mathrm{a}}$ & - & - & - & - & $0.522^{\mathrm{a}}$ & - \\
\hline $\mathrm{HCB}$ & - & - & - & - & - & - & $0.647^{\mathrm{b}}$ & $0.438^{\mathrm{a}}$ & $0.591^{\mathrm{b}}$ & - & - & - \\
\hline PCB 28 & - & - & - & - & - & - & - & - & $0.469^{\mathrm{a}}$ & - & - & - \\
\hline PCB 52 & - & - & - & - & - & - & - & - & $0.482^{\mathrm{a}}$ & - & - & - \\
\hline РCB 101 & $0.658^{\mathrm{b}}$ & - & - & - & - & - & $0.520^{\mathrm{b}}$ & $0.478^{\mathrm{a}}$ & $0.763^{b}$ & - & - & - \\
\hline
\end{tabular}

a Significance at $95 \%$ confidence level. ${ }^{\text {b }}$ Significance at $99 \%$ confidence level.

temperature, precipitation, and \% of monthly air mass trajectories arriving at each site have been calculated. The statistically significant correlations found in each site at $95 \%$ $(p<0.05)$ and $99 \%(p<0.01)$ confidence levels are reported in Tables 4 and 5.

Endosulfan sulfate is the only compound found to correlate significantly with temperature in all four sites (Table 4), which results in a clear seasonal trend with higher deposition fluxes during the warm than in the cold periods (Fig. 2). As mentioned in the previous section, this compound is generated by transformation of endosulfans which are widely used in agriculture. Accordingly, the positive correlation between endosulfan sulfate and temperature is reflecting the seasonal use of the precursors. Positive significant correlations of endosulfans and temperature are observed in Skalnaté and Redòn for the $\beta$-isomer and in Skalnaté and Lochnagar for the $\alpha$-isomer. The seasonal pesticide trends in Skalnaté and Redòn have been related to increasing air concentrations as a consequence of their field use during the warm period (Carrera et al., 2002; Brun et al., 2008; Aulagnier and Poissant, 2005; Carlsson et al., 2004). This trend is only observed for the degradation product in Gossenköllesee which may reflect significant degradation during transport to the highest altitude site among those considered in the present study. The same cause is due to the significant correlation of $\gamma-\mathrm{HCH}$ and temperature in Redòn, Skalnaté and Lochnagar, the lack of correlation in Gossenköllesee may again be due to the high altitude of this site which dampens the inputs from the agricultural activity developed at lower altitude.

Significant temperature dependences are observed in Skalnaté for HCB and PCB 101, PCB 118 and PCB 153
(Table 4). This site is the one receiving highest deposition of these compounds (Table 2). The significant temperature dependence is probably related to emission from secondary sources reflecting past uses of these compounds (Carrera et al., 2002; Dickhut and Gustafson, 1995), e.g. influence of industrial spills from the Upper Silesian or the black triangle industrial areas. The deposition of the PCB congeners with volatilities in the range of $3.2 \times 10^{-3} \mathrm{~Pa}$ and $5.5 \times 10^{-4} \mathrm{~Pa}$ in this elevated site (temperatures in the range of -9.2 and $9.0^{\circ} \mathrm{C}$, Table 1) suggest that the other $\mathrm{PCB}$ congeners are either too volatile $>3.5 \times 10^{-3} \mathrm{~Pa}$, e.g. PCB 28 and PCB 52, to show an increase in their concentration in deposition, or of insufficient volatility $<5.4 \times 10^{-4} \mathrm{~Pa}$, e.g. PCB 138 and PCB 180 , to be re-emitted significantly to the atmosphere. In this sense, no relationship between PCB deposition to remote sites and temperature has been observed in the southern Mediterranean Sea (Mandalakis and Stephanou, 2004), and even negative correlations have been reported between PCB deposition fluxes and temperature (Agrell et al., 2002, and references herein) which have been attributed to enhanced partitioning of these compounds to particles at low temperatures and increased scavenging efficiency of snow compared to rain.

Skalnate is also the only site in which significant positive associations are observed between most compounds and particle deposition, e.g. $\alpha-\mathrm{HCH}, \gamma-\mathrm{HCH}, \alpha$-endosulfan, $\beta$-endosulfan, endosulfan sulfate, HCB, PCB 28, PCB 52, PCB 101, PCB 118 and PCB 153. In Redòn, there is nearly the same atmospheric deposition flux of particles (Table 1) and no association with any of these compounds is observed (Table 4). Thus, these associations are related to the high de- 
Table 5. Linear regression analysis between OC deposition fluxes $\left(\mathrm{ng} \mathrm{m}^{-2} \mathrm{mo}^{-1}, \log\right.$-transformed values), monthly mean temperature ( $T$, ${ }^{\circ} \mathrm{C}$ ), precipitation (Precip, $\left.\mathrm{mm} \mathrm{mo}^{-1}\right)$, particle deposition $\left(\mathrm{mg} \mathrm{m}^{-2} \mathrm{mo}^{-1}\right.$, log-transformed values) and $\%$ air masses flowing from the west in Skalnaté. Only compounds with statistically significant multilinear regression model are included.

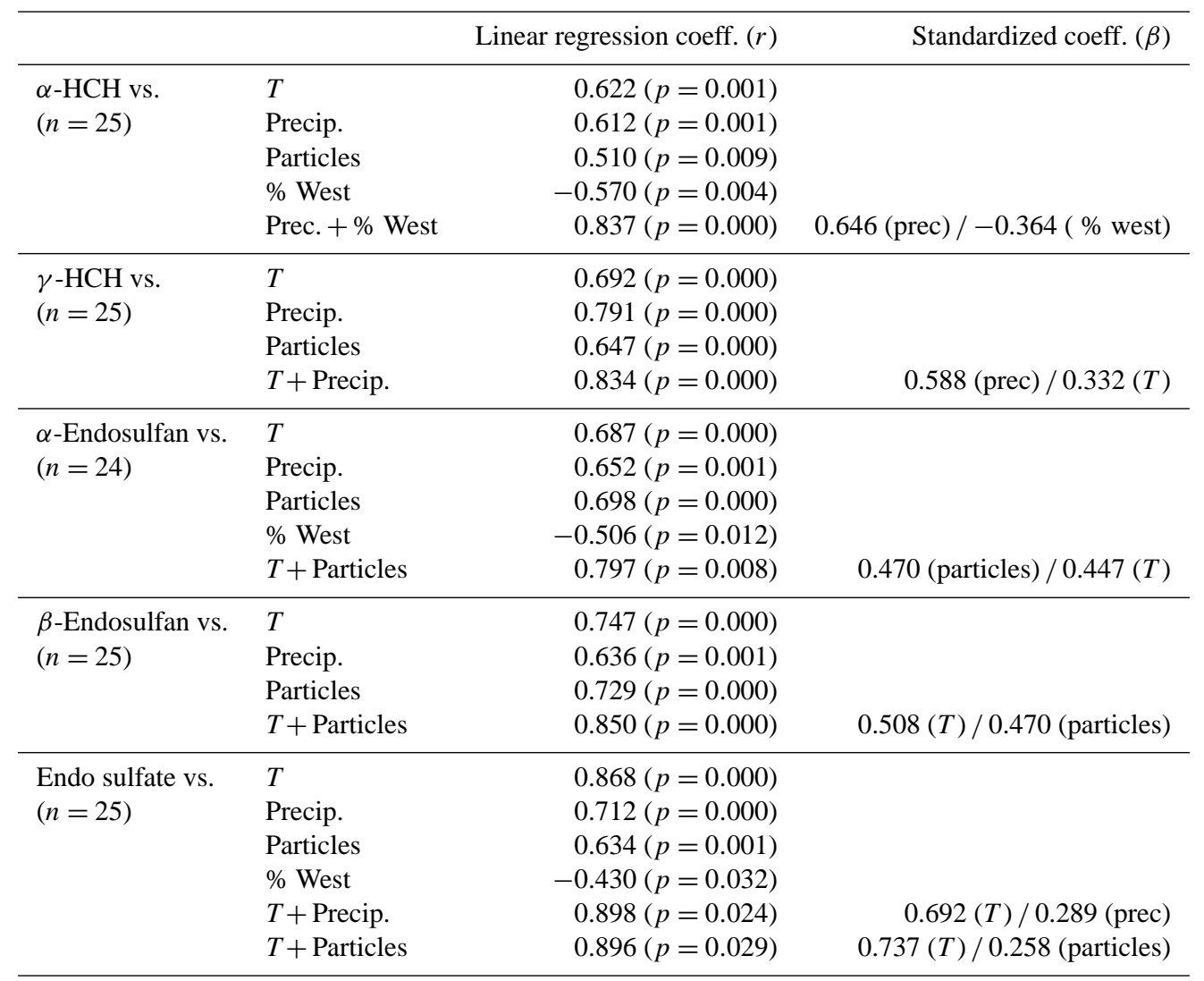

Multilevel regression coefficients are indicated only if all considered variables in the model showed a significant correlation at least at $95 \%$ confidence level.

position fluxes of these compounds in this site (Table 2) as a consequence of regional past spills of these pollutants and not to the high deposition of particles (Table 1).

Skalnaté is also the site in which atmospheric deposition of most OCs is related to wet precipitation (Table 4). The high number of significant positive correlations is a consequence of the regional spills which involved high emissions from secondary sources. The effect of wet precipitation is also noticed in the correlation with atmospheric deposition of the PCB congeners of lowest volatility, e.g. PCB 180 $\left(1.3 \times 10^{-4} \mathrm{~Pa}\right)$, which probably are associated with suspended particles that are carried down with rain events. These rain events are also significant in the atmospheric deposition of Redòn and Lochnagar but not in Gossenköllesee, the highest site at $2413 \mathrm{~m}$ (Table 1), where least rain was recorded (1722 mm, Table 1).

As already mentioned for PCBs, correlation between deposition fluxes and precipitation, temperature or particle deposition has been observed for most of the study compounds in Skalnaté. Examination of the correlation between independent variables shows interdependences, involving that $26 \%$ of the particle deposition variance and $37 \%$ of the precipitation variance are explained by temperature, which makes it difficult to establish the main factor controlling OC deposition fluxes in this remote site.

Multilinear regression analysis using all independent variables (Table 5) indicates that for some PCB congeners and $\mathrm{HCB}$, the factors accounting for most of the variance are precipitation (HCB, PCB 118 and PCB 180) and particle deposition (PCB 101 and PCB 153) as sole independent variables. For pesticides, the combination of precipitation and temperature for $\mathrm{HCHs}$ and particle deposition and temperature for endosulfans accounted for $70 \%$ and $64-80 \%$ of the variance, respectively (Table 5). Based on the standardized coefficients in multilinear regression analysis, precipitation is the main factor controlling $\mathrm{HCH}$ deposition fluxes to this site, whereas in the case of endosulfan isomers, two variables, temperature and particle deposition, have similar influence. Finally, for endosulfan sulfate, temperature is the dominant factor. 
Table 6. Pearson correlation coefficients between OC deposition fluxes and \% of air masses from different origins at the study sites.

\begin{tabular}{|c|c|c|c|c|c|c|c|c|c|c|c|}
\hline & \multirow[b]{2}{*}{$\begin{array}{r}\text { Central/east } \\
\text { Europe }\end{array}$} & \multicolumn{3}{|c|}{ Redòn } & \multicolumn{3}{|c|}{ Gossenköllesee } & \multicolumn{2}{|c|}{ Skalnaté } & \multicolumn{2}{|c|}{ Lochnagar } \\
\hline & & South & $\begin{array}{r}\mathrm{N} . \\
\text { Atlantic }\end{array}$ & $\begin{array}{r}\text { N. Atlantic } \\
\text { (west) }\end{array}$ & $\begin{array}{r}\text { Central/east } \\
\text { Europe }\end{array}$ & South & $\begin{array}{r}\mathrm{N} . \\
\text { Atlantic }\end{array}$ & West & $\begin{array}{l}\text { North } \\
\text { Polar }\end{array}$ & $\begin{array}{l}\text { North } \\
\text { Polar }\end{array}$ & South \\
\hline$\alpha-\mathrm{HCH}$ & - & - & - & - & - & - & - & $-0.411^{\mathrm{a}}$ & - & - & - \\
\hline$\gamma-\mathrm{HCH}$ & $-0.456^{\mathrm{a}}$ & $0.694^{b}$ & - & - & - & - & - & - & - & - & _- \\
\hline$\alpha / \gamma-\mathrm{HCH}$ & - & $-0.530^{\mathrm{a}}$ & $0.560^{\mathrm{b}}$ & $0.584^{\mathrm{b}}$ & $0.478^{\mathrm{a}}$ & - & - & - & - & - & - \\
\hline$\alpha$-endosulfan & - & - & - & - & - & - & - & $-0.506^{\mathrm{a}}$ & - & - & - \\
\hline$\beta$-endosulfan & - & - & - & - & - & - & $-0.647^{\mathrm{b}}$ & - & - & - & $0.499^{\mathrm{a}}$ \\
\hline Endo sulfate & $-0.606^{\mathrm{b}}$ & $0.602^{\mathrm{b}}$ & - & - & - & - & $-0.480^{\mathrm{a}}$ & $-0.430^{\mathrm{a}}$ & - & - & - \\
\hline$\alpha / \beta$-endosulf & - & - & $0.540^{\mathrm{a}}$ & - & - & - & - & - & - & - & - \\
\hline$\sum$ Endosulf & $-0.569^{\mathrm{a}}$ & $0.567^{\mathrm{a}}$ & - & - & - & $0.455^{\mathrm{a}}$ & - & - & - & - & - \\
\hline $\mathrm{HCB}$ & - & - & - & - & - & - & - & - & - & - & - \\
\hline PCB 28 & - & - & - & - & - & - & - & $-0.452^{\mathrm{a}}$ & - & - & - \\
\hline PCB 52 & - & - & - & - & - & - & - & - & - & - & - \\
\hline PCB 101 & - & - & - & $0.538^{\mathrm{a}}$ & - & - & - & $-0.446^{\mathrm{a}}$ & - & - & - \\
\hline PCB 118 & - & - & - & $0.448^{\mathrm{a}}$ & - & - & - & - & - & - & - \\
\hline PCB 153 & - & - & - & - & - & - & - & $-0.456^{\mathrm{a}}$ & - & - & - \\
\hline PCB 138 & - & - & - & $0.447^{\mathrm{a}}$ & - & - & - & - & $-0.426^{\mathrm{a}}$ & $-0.454^{\mathrm{a}}$ & - \\
\hline PCB 180 & $-0.590^{\mathrm{b}}$ & - & - & - & - & - & - & - & - & - & - \\
\hline Precipitation & - & - & - & $0.504^{\mathrm{a}}$ & - & - & - & - & - & - & - \\
\hline Temperature & - & $0.805^{\mathrm{b}}$ & $-0.608^{\mathrm{b}}$ & - & - & - & - & $-0.411^{\mathrm{a}}$ & - & - & - \\
\hline Particle flux & - & $0.498^{\mathrm{a}}$ & - & - & - & - & - & $-0.428^{\mathrm{a}}$ & $-0.414^{\mathrm{a}}$ & - & - \\
\hline
\end{tabular}

a Significant at $95 \%$ confidence level. ${ }^{\text {b }}$ Significant at $99 \%$ confidence level.

\subsection{Influence of air mass origin}

Further insight into the factors determining OC deposition in these remote sites can be obtained by investigation of the relationship with the main air mass trajectories arriving at each sampling site (Arellano et al., 2014). No statistically significant correlations between PCB deposition fluxes and air mass origin in Gossenköllesee and Lochnagar have been observed (Table 6), which is consistent with a diffuse pollution from unspecific sources, likely related to secondary emissions, as the main origin of PCBs arriving at these remote sites. In contrast, significant correlations of PCB fluxes and prevailing air masses have been observed in Redòn and Skalnaté. In Redòn, significantly higher deposition fluxes of PCB 101, PCB 118 and PCB 138 were found to be associated with air masses flowing from the west North Atlantic, while in Skalnaté a significant decrease of fluxes of some PCB congeners is found in conjunction with air masses coming from the west (Table 6). Significant correlations between these air mass trajectories and meteorological variables have also been found in both sites. Thus, in Redòn the west North Atlantic air masses are significantly associated with higher precipitation fluxes, while negative correlations between $\%$ air masses from the west and temperature or particle deposition were observed in Skalnaté (Table 6). Given these results, the observed variations in PCB fluxes associated with certain air masses could reflect an indirect consequence of the aforementioned relationship between PCB deposition fluxes and meteorological variables. In fact, no statistical significance of the percent contribution of west air masses as independent variable was found in the multilinear regression analysis of the deposition fluxes in Skalnaté (Table 5).

Higher deposition fluxes of HCHs and endosulfans were associated with air masses coming from the south in Redòn (Table 6). In addition, a decrease in $\alpha / \gamma-\mathrm{HCH}$ ratio was also observed related to this air mass trajectory, indicating significant contributions of lindane coming from southern Europe. However, the correlation found between temperature and $\%$ contribution of backwards air mass trajectories from the south in Redòn does not allow ruling out temperature as the main factor controlling $\mathrm{HCH}$ and endosulfan levels at this site.

For Gossenköllesee, statistically significant correlations were found between $\beta$-endosulfan and endosulfan sulfate and percent of air masses from the North Atlantic, involving lower concentrations at higher contribution of air masses from this origin. Conversely, positive correlations were found between total endosulfans and back-trajectories coming from the south (North Africa, Mediterranean Sea and/or Iberian Peninsula) in this site as well as in Lochnagar, which is consistent with the potential emission sources of this pesticide from areas of intensive agricultural activities. In addition, back-trajectories from central/east Europe corresponded to higher $\alpha / \gamma-\mathrm{HCH}$ ratios in Gossenköllesee according with the prevalent use of technical $\mathrm{HCH}$ in eastern Europe (Halse et al., 2011) and the impact of air pollution transported from the east at this site (Kaiser, 2009). 


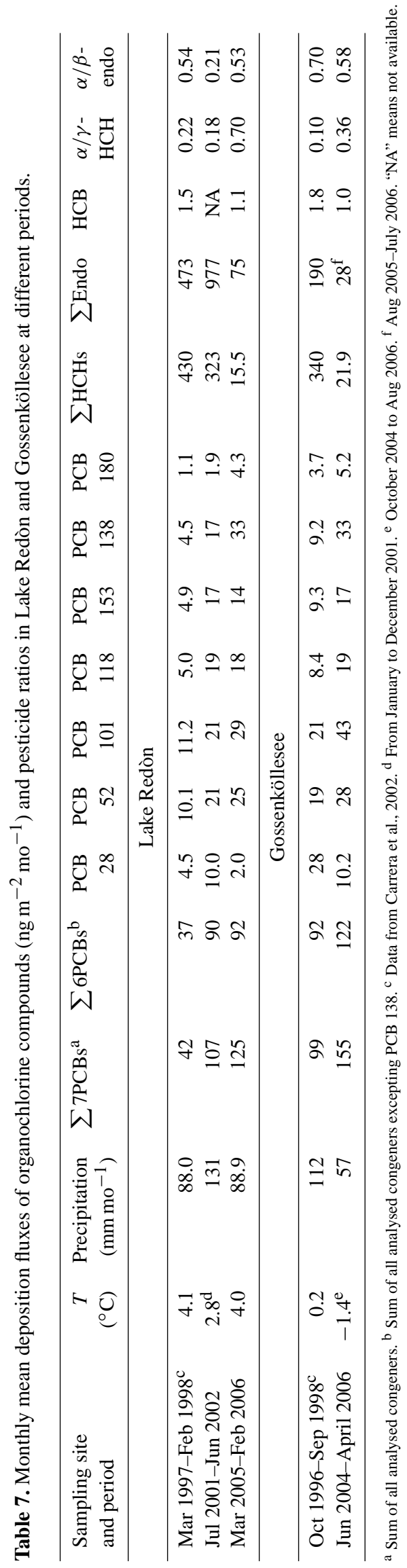



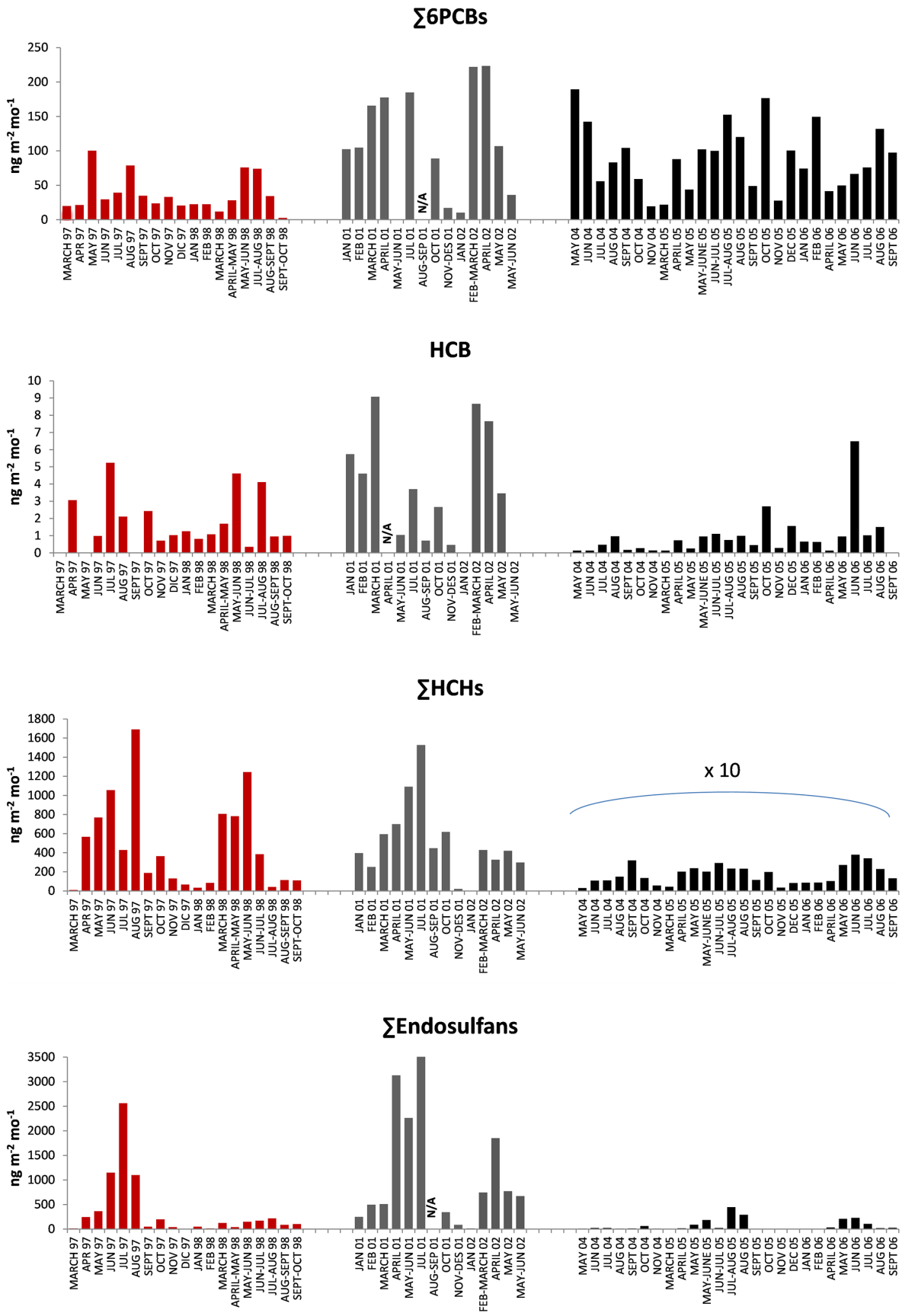

Sampling period

Figure 3. Temporal trends of $\mathrm{OC}$ concentrations in bulk atmospheric deposition samples from Redòn. N/A means not available. $\sum 6 \mathrm{PCBs}$, sum of PCB 28, 52, 101, 118, 153 and 180. $\sum \mathrm{HCHs,} \mathrm{sum} \mathrm{of} \alpha-\mathrm{HCH}$ and $\gamma-\mathrm{HCH}$. $\sum$ Endosulfans, sum of $\alpha$-endosulfan, $\beta$-endosulfan and endosulfan sulfate.

\subsection{Long-term trends of atmospheric deposition of OCs to remote sites}

In addition to the data reported in the present study, OC deposition fluxes were also measured in 1996-1998 at Gossenköllesee and 1997-1998 at Redòn (Carrera et al.,
2002). Moreover, OC monthly deposition samples were measured at Redòn between July 2001 and June 2002. The combination of these series provides a deposition database over 1 decade, which despite its discontinuities allows us to assess the long-term temporal trends of atmospheric precipitation of these pollutants in the European background sites. As indi- 
cated above, the previous studies showed a seasonal trend in OC deposition fluxes, with higher values during warm seasons. In view of this, we have calculated mean monthly deposition fluxes for complete annual periods to avoid the influence of this seasonality when comparing between different time periods (Table 7).

Concerning the studied pesticides, $\mathrm{HCHs}$ and endosulfans deposition fluxes decline significantly $(p<0.001)$ both at Redòn and Gossenköllesee, involving decreases of up to 1 order of magnitude (Table 7, Fig. 3). In previous studies, $\mathrm{HCH}$ deposition at Redòn and Gossenköllesee was characterized by background levels with several peak fluxes during the warm season following their application in the fields. In the present study, the $\mathrm{HCH}$ deposition fluxes showed more uniform values throughout the year (Fig. 3), consistent with inputs from diffusive pollution by re-evaporation of past usages. Declines are observed for both $\alpha$ - and $\gamma-\mathrm{HCH}$, although they are more pronounced for the latter as inferred from the increase in $\alpha / \gamma-\mathrm{HCH}$ ratios observed at both sites (Table 7). These differences between isomers can be explained by volatility differences but also by the higher environmental persistence of the $\alpha$ - than the $\gamma$-isomer. In this sense, the conversion of $\gamma-\mathrm{HCH}$ to $\alpha-\mathrm{HCH}$ in air by photoisomerization and the lower degradation rate of $\alpha-\mathrm{HCH}$ than $\gamma-\mathrm{HCH}$ by reaction with hydroxyl radicals in the gas phase have been reported (Brun et al., 2008).

Closer examination of the pesticide concentrations at Redòn indicates that the main decline in deposition started after 2001-2002, which is consistent with the general phaseout of HCHs as well as the discontinuation of endosulfan production that took place in most European countries between 2000 and 2004 (Weber et al., 2010; Li and Vijgen, 2006). Significant declines were also observed in $\alpha-\mathrm{HCH}$ and $\gamma-\mathrm{HCH}$ concentrations in atmospheric precipitation and air from different sites in Norway, Denmark and Sweden during 19962009 (Tørseth et al., 2012), in the Arctic atmosphere (Brun et al., 2008), and in wet deposition and air in the Czech Republic for the period 1996-2005 (Holoubek et al., 2007).

In contrast, the PCB deposition fluxes measured during 2004-2006 are higher than those found in 1996-1998 (155 and $125 \mathrm{ng} \mathrm{m}^{-2} \mathrm{mo}^{-1}$ vs. 99 and $42 \mathrm{ng} \mathrm{m}^{-2} \mathrm{mo}^{-1}$, at Gossenköllesee and Redòn, respectively; Table 7), although the differences were only statistically significant at Redòn $(p<0.05)$. Similar differences have been observed at Redòn in relation to the samples taken in 2001-2002. Mean PCB deposition fluxes during this period, $110 \mathrm{ng} \mathrm{m}^{-2} \mathrm{mo}^{-1}$, were higher than the levels measured in 1997-1998, and lower (but not statistically different) than those found in 2004-2006 (Table 7).

PCB 138 is the congener showing a strongest increase in the last period measured, 2004-2006, by reference to the time interval sampled in 1996-1998 (Table 7). No interferences in the determination of this congener have been observed; however, in order to avoid the influence of an overestimation of PCB 138 concentrations in temporal trend anal-

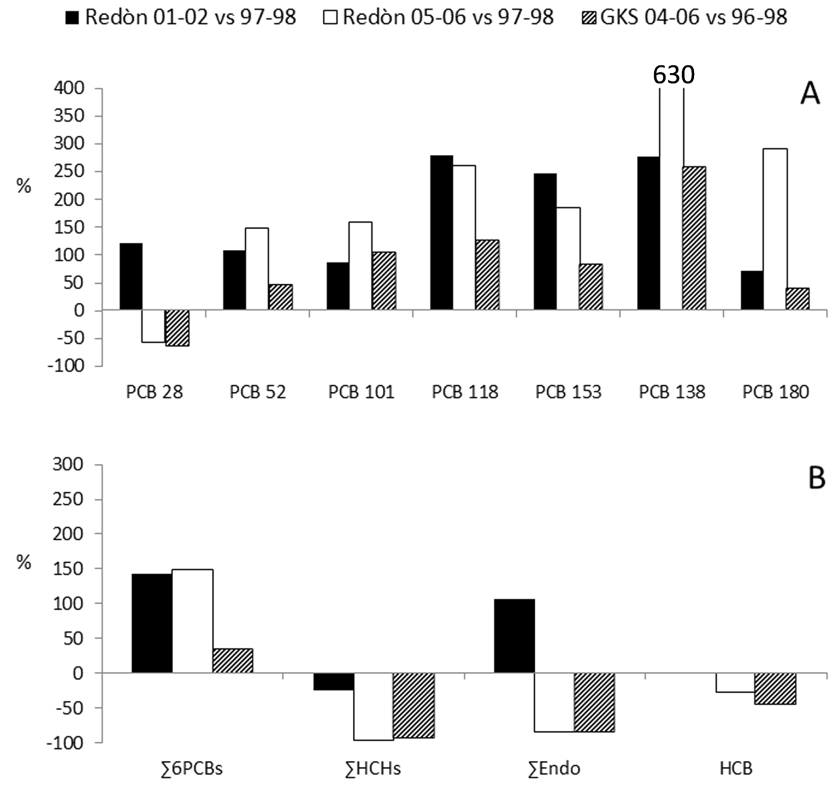

Figure 4. Percentage increase or decrease of atmospheric deposition fluxes of individual PCB congeners (a) and OCs (b) at Redòn and Gossenköllesee (GKS) during the study periods.

ysis, this congener was removed from the total PCB data set. Calculation of the atmospheric deposition differences excluding this compound also shows an increase of PCB deposition between these two time periods (Table 7). As shown in Fig. 4, the deposition increases are more pronounced at Redòn than at Gossenköllesee and for the high chlorinated PCBs than for the more volatile congeners.

Average local air temperatures show small decreases, from 0.2 to $-1.4{ }^{\circ} \mathrm{C}$ at Gossenköllesee station, and no defined trend, 4.1 and $4.0^{\circ} \mathrm{C}$ at Redòn, during the sampling period (Table 7). Thus, the increase in atmospheric deposition cannot be attributed to deposition by precipitation trapping of volatilized PCBs from nearby sources. Furthermore, water precipitation hardly changed at Redòn, from 88 to $89 \mathrm{~mm} \mathrm{mo}^{-1}$, and decreased at Gossenköllesee, from 112 to $57 \mathrm{~mm} \mathrm{mo}^{-1}$ (Table 7). Precipitation changes cannot, therefore, explain the increase in PCB deposition. In fact, the precipitation decrease in Gossenköllesee may perhaps have counteracted the trend towards higher PCB deposition and for this reason the observed increases in deposition of these compounds are stronger at Redòn.

A priori, an increasing trend of PCB deposition fluxes in remote regions is not expected since the global production of these compounds strongly decreased in the 1970s and was stopped in the 1980s. In fact, declines in PCB air concentrations as a consequence of the ban of these compounds have been reported (Holoubek et al., 2007; Halse et al., 2011; Schuster et al., 2010). However, in remote areas such as Svalbard (Norway) and the Canadian Arctic (Hung et al., 2010) increases of PCB air concentrations have been observed, be- 
ing attributed to the remobilization of these compounds from Arctic reservoirs like waters, soils and snow/ice as a result of sea-ice retreat and rising temperatures induced by climate change (Ma et al., 2011). Analogously, melting glaciers in high mountain regions have been suggested as potential secondary sources of POPs released to Alpine lakes (Schmid et al., 2011; Blais et al., 2001), especially for PCBs (Bogdal et al., 2010). Indeed, increasing concentrations of POPs have been recently observed in sediments of Lake Oberaar, a glacier-fed lake in Switzerland, and the trend was attributed to glacier melting and remobilization of ice-trapped compounds (Bogdal et al., 2009). Taking into account that high European mountain regions are enriched in more chlorinated PCBs due to selective accumulation in these cold areas (Grimalt et al., 2001, 2004b, 2009), we hypothesize that re-emission of these pollutants as a consequence of glacier melting could be responsible for the observed higher contribution of these congeners to the atmospheric deposition samples collected in 2001-2002 and 2004-2006 with respect to those collected in 1996-1998 and the increasing concentrations observed in their long-term temporal trends.

The Henry's law constants of PCBs, $31-53 \mathrm{~Pa} \mathrm{~m}^{3} \mathrm{~mol}^{-1}$ (Bamford et al., 2000), can explain the transfer to the atmosphere of at least a portion of the trapped congeners upon ice melting. This is not the case of the HCHs or endosulfans whose Henry's law constants, 0.74, 0.31 and 0.045$0.70 \mathrm{~Pa} \mathrm{~m}^{3} \mathrm{~mol}^{-1}$ for $\alpha-\mathrm{HCH}, \gamma-\mathrm{HCH}$ and endosulfans, respectively (Shen and Wania, 2005; Xiao et al., 2004), tend to retain these compounds dissolved in water after ice melting. Thus, besides influences related to the changes in use of these compounds during the sampling period, their physicalchemical constants do not allow their transfer to the atmosphere in significant proportion upon ice melting and therefore decreases in atmospheric deposition were observed (Table 7).

HCB exhibits small decreases in deposition values during this sampling period (Table 7). However, air increases during 1995-2005 have been reported in the Czech Republic (Holoubek et al., 2007), as well as in Arctic air (early- to mid-2000s; Hung et al., 2010). Decreases in precipitation of this compound have been observed by the EMEP network (European Monitoring and Evaluation Programme) in several European sites (Tørseth et al., 2012). HCB exhibits an elevated volatility, $6.3 \times 10^{-2} \mathrm{~Pa}$, and long atmospheric halflife, more than 700 days (Gramatica and Papa, 2007). These characteristics confer high atmospheric mobility and limited spatial variability of HCB in remote regions (Tørseth at al., 2012). Therefore it would be difficult to observe significant changes in HCB levels in atmospheric deposition over a period of 10 years.

The long-term trends of OCs found in this study suggest that regulatory efforts to decrease the emission of these compounds, e.g. pesticides, to the environment have been effective in a first stage but remobilization of some compounds, such as PCBs or HCB, previously accumulated in sink com- partments may limit the effectiveness of these international control regulations.

Author contributions. L. Arellano carried out sample processing and OC analysis of the samples taken between 2004 and 2007 and performed the backward air mass trajectory calculations. R. Fonts analysed samples from Redòn taken in 2001-2002. Sampling and other field work were designed and performed at each site by N. Rose (Lochnagar), U. Nickus and H. Thies (Gossenköllesee), E. Stuchlík (Skalnaté), and L. Camarero (Redòn). P. Fernández performed data interpretation and prepared the paper with contributions from all co-authors, especially J. Grimalt.

Acknowledgements. Financial support from the EU Projects EUROLIMPACS (GOCE-CT-2003-505540), ArcRisk (FP7ENV-2008-1-226534), GRACCIE (CSD2007-00067) and grant No.14-09231S of the Czech Science Foundation is acknowledged. The Geophysical Institute of the Slovak Academy of Sciences, in particular S. Bičárová, O. Jakubják and I. Bohuš, is thanked for help during the study in Skalnaté Pleso meteorological observatory and for providing data on air temperature.

Edited by: L. Zhang

\section{References}

Agrell, C., Larsson, P., Okla, L., and Agrell, J.: PCB congeners in precipitation, wash out ratios and depositional fluxes within the Baltic Sea region, Europe, Atmos. Environ., 36, 371-383, 2002.

Arellano, L., Fernández, P., Tatosova, J., Stuchlik, E., and Grimalt, J. O.: Long-Range Transported Atmospheric Pollutants in Snowpacks Accumulated at Different Altitudes in the Tatra Mountains (Slovakia), Environ. Sci. Technol., 45, 9268-9275, 2011.

Arellano, L., Fernández, P., López, J. F., Rose, N. L., Nickus, U., Thies, H., Stuchlik, E., Camarero, L., Catalan, J., and Grimalt, J. O.: Atmospheric deposition of polybromodiphenyl ethers in remote mountain regions of Europe, Atmos. Chem. Phys., 14, 4441-4457, doi:10.5194/acp-14-4441-2014, 2014.

Aulagnier, F. and Poissant, L.: Some Pesticides Occurrence in Air and Precipitation in Quebec, Canada, Environ. Sci. Technol., 39, 2960-2967, 2005.

Bamford, H. A., Poster, D. L., and Baker, J. E.: Henry's Law Constants of polychlorinated biphenyl congeners and their variation with temperature, J. Chem. Eng. Data, 45, 1069-1074, 2000.

Becker, S., Halsall, C. J., Tych, W., Kallenborn, R., Su, Y., and Hung, H.: Long-term trends in atmospheric concentrations of alpha- and gamma-HCH in the Arctic provide insight into the effects of legislation and climatic fluctuations on contaminant levels., Atmos. Environ., 42, 8225-8233, 2008.

Blais, J. M., Schindler, D. W., Muir, D. C. G., Kimpe, L. E., Donald, D. B., and Rosenberg, B.: Accumulation of Persistent Organochlorine Compounds in Mountains of Western Canada, Nature, 395, 585-588, 1998.

Blais, J. M., Schindler, D. W., Muir, D. C. G., Sharp, M., Donald, D., Lafrenière, M., Braekevelt, E., and Strachan, W. M. J.: Melting Glaciers: A Major Source of Persistent Organochlorines to 
Subalpine Bow Lake in Banff National Park, Canada, Ambio, 30, 410-415, 2001.

Blanchard, P., Kallweit, D., Brice, K. A., Froude, F. A., Chan, C. H., Neilson, M., Holz, J., and Millat, H.: A comparison of European and North American atmospheric deposition networks: Polycyclic aromatic hydrocarbons and lindane, J. Environ. Monitor., 8, 465-471, 2006.

Bogdal, C., Schmid, P., Zennegg, M., Anselmetti, F. S., Scheringer, M., and Hungerbühler, K.: Blast from the Past: Melting Glaciers as a Relevant Source for Persistent Organic Pollutants, Environ. Sci. Technol., 43, 8173-8177, 2009.

Bogdal, C., Nikolic, D., Lüthi, M. P., Schenker, U., Scheringer, M., and Hungerbühler, K.: Release of Legacy Pollutants from Melting Glaciers: Model Evidence and Conceptual Understanding, Environ. Sci. Technol., 44, 4063-4069, 2010.

Brun, G. L., MacDonald, R. M., Verge, J., and Aubé, J.: Long-term atmospheric deposition of current-use and banned pesticides in Atlantic Canada; 1980-2000, Chemosphere, 71, 314-327, 2008.

Cabrerizo, A., Dachs, J., Barceló, D., and Jones, K. C.: Influence of Organic Matter Content and Human Activities on the Occurrence of Organic Pollutants in Antarctic Soils, Lichens, Grass, and Mosses, Environ. Sci. Technol., 46, 1396-1405, 2012.

Carlsson, D. L., Basu, I., and Hites, R. A.: Annual Variations of Pesticide Concentrations in Great Lakes Precipitation, Environ. Sci. Technol., 38, 5290-5296, 2004.

Carrera, G., Fernández, P., Vilanova, R., and Grimalt, J. O.: Analysis of Trace Polycyclic Aromatic Hydrocarbons and Organochlorine Compounds in Atmospheric Residues by Solid-Phase Disk Extraction, J. Chromatogr. A, 823, 189-196, 1998.

Carrera, G., Fernández, P., Vilanova, R. M., and Grimalt, J. O.: Persistent organic pollutants in snow from European high mountain areas, Atmos. Environ. 35, 245-254, 2001.

Carrera, G., Fernández, P., Grimalt, J. O., Ventura, M., Camarero, L., Catalán, J., Nickus, U., Thies, H., and Psenner, R.: Atmospheric Deposition of Organochlorine Compounds to Remote High Mountain Lakes of Europe, Environ. Sci. Technol., 36, 2587-2588, 2002.

Daly, G. L. and Wania, F.: Organic Contaminants in Mountains, Environ. Sci. Technol., 39, 385-398, 2005.

Davidson, D. A., Wilkinson, A. C., Blais, J. M., Kimpe, L. E., McDonald, K. M., and Schindler, D. W.: Orographic Cold-Trapping of Persistent Organic Pollutants by Vegetation in Mountains of Western Canada, Environ. Sci. Technol., 37, 209-215, 2003.

de Souza Pereira, M., Heitmann, D., Reifenhäuser, W., Meire, R. O., Santos, L. S., Torres, J. P. M., Malm, O., and Körner, W.: Persistent organic pollutants in atmospheric deposition and biomonitoring with Tillandsia usneoides (L.) in an industrialized area in Rio de Janeiro state, southeast Brazil - Part II: PCB and PAH, Chemosphere, 67, 1736-1745, 2007.

Dickhut, R. M. and Gustafson, K. E.: Atmospheric Inputs of Selected Polycyclic Aromatic Hydrocarbons and Polychlorinated Biphenyls to Southern Chesapeake Bay, Mar. Pollut. Bull., 30, 385-396, 1995.

Estellano, V. H., Pozo, K., Harner, T., Franken, M., and Zaballa, M.: Altitudinal and Seasonal Variations of Persistent Organic Pollutants in the Bolivian Andes Mountains, Environ. Sci. Technol., 42, 2528-2534, 2008.

Fernández, P. and Grimalt, J. O.: On the Global Distribution of Persistent Organic Pollutants, Chimia, 57, 514-521, 2003.
Fernández, P., Vilanova, R. M., and Grimalt, J. O.: Sediment Fluxes of Polycyclic Aromatic Hydrocarbons in European High Altitude Mountain Lakes, Environ. Sci. Technol., 33, 3716-3722, 1999.

Fernández, P., Carrera, G., Grimalt, J. O., Ventura, M., Camarero, L., Catalán, J., Nickus, U., Thies, H., and Psenner, R.: Factors Governing the Atmospheric Deposition of Polycyclic Aromatic Hydrocarbons to Remote Areas, Environ. Sci. Technol., 37, 3261-3267, 2003.

Franz, T. P. and Eisenreich, S. J.: Wet deposition of polychlorinated biphenyls to Green Bay, Lake Michigan, Chemosphere, 26, 1767-1788, 1993.

Gioia, R., Offenberg, J. H., Gigliotti, C. L., Totten, L. A., Du, S., and Eisenreich, S. J.: Atmospheric concentrations and deposition of organochlorine pesticides in the US Mid-Atlantic region, Atmos. Environ., 39, 2309-2322, 2005.

Goel, A., McConnell, L. L., and Torrents, A.: Wet Deposition of Current Use Pesticides at a Rural Location on the Delmarva Peninsula: Impact of Rainfall Patterns and Agricultural Activity, J. Agricul. Food Chem., 53, 7915-7924, 2005.

Gramatica, P. and Papa, E.: Screening and Ranking of POPs for Global Half-Life: QSAR Approaches for Prioritization Based on Molecular Structure, Environ. Sci. Technol., 41, 2833-2839, 2007.

Grimalt, J. O., Fernández, P., Berdié, L., Vilanova, R. M., Catalan, J., Psenner, R., Hofer, R., Appleby, P. G., Lien, L., Rosseland, B. O., Massabuau, J.-C., and Battarbee, R. W.: Selective Trapping of Organochlorine Compounds in Mountain Lakes of Temperate Areas, Environ. Sci. Technol., 35, 2690-2697, 2001.

Grimalt, J. O., Borghini, F., Sanchez-Hernandez, J. C., Barra, R., Garcia, C. J. T., and Focardi, S.: Temperature dependence of the distribution of organochlorine compounds in the mosses of the Andean Mountains, Environ. Sci. Technol., 38, 5386-5392, $2004 a$.

Grimalt, J. O., van Drooge, B. L., Ribes, A., Vilanova, R. M., Fernandez, P., and Appleby, P.: Persistent organochlorine compounds in soils and sediments of European high mountain lakes, Chemosphere 54, 1549-1561, 2004b.

Grimalt, J. O., Fernandez, P., and Quiroz, R.: Input of organochlorine compounds by snow to European high mountain lakes, Freshwater Biol., 54, 2533-2542, 2009.

Guazzoni, N., Comolli, R., Mariani, L., Cola, G., Parolini, M., Binelli, A., and Tremolada, P.: Meteorological and pedological influence on the PCBs distribution in mountain soils, Chemosphere, 83, 186-192, 2011.

Hageman, K. J., Simonich, S. L., Campbell, D. H., Wilson, G. R., and Landers, D. H.: Atmospheric Deposition of Current-Use and Historic-Use Pesticides in Snow at National Parks in the Western United States, Environ. Sci. Technol., 40, 3174-3180, 2006.

Halsall, C. J.: Investigating the occurrence of persistent organic pollutants (POPs) in the Arctic: Their atmospheric behaviour and interaction with the seasonal snow pack, Environ. Poll., 128, 163175, 2004.

Halse, A. K., Schlabach, M., Eckhardt, S., Sweetman, A., Jones, K. C., and Breivik, K.: Spatial variability of POPs in European background air, Atmos. Chem. Phys., 11, 1549-1564, doi:10.5194/acp-11-1549-2011, 2011.

Hillery, B. R., Simcik, M. F., Basu, I., Hoff, R. M., Strachan, W. M. J., Burniston, D., Chan, C. H., Brice, K. A., Sweet, C. W., and Hites, R. A.: Atmospheric Deposition of Toxic Pollutants to the 
Great Lakes as Measured by the Integrated Atmospheric Deposition Network, Environ. Sci. Technol., 32, 2216-2221, 1998.

Holoubek, I., Klánová, J., Jarkovský, J., and Kohoutek, J.: Trends in background levels of persistent organic pollutants at Kosetice observatory, Czech Republic. Part I. Ambient air and wet deposition 1996-2005, J. Environ. Monitor., 9, 557-563, 2007.

Hung, H., Kallenborn, R., Breivik, K., Su, Y., Brorström-Lundén, E., Olafsdottir, K., Thorlacius, J. M., Leppänen, S., Bossi, R., Skov, H., Manø, S., Patton, G. W., Stern, G., Sverko, E., and Fellin, P.: Atmospheric monitoring of organic pollutants in the Arctic under the Arctic Monitoring and Assessment Programme (AMAP): 1993-2006, Sci. Total Environ., 408, 2854-2873, 2010.

Jantunen, L. M., Helm, P. A., Kylin, H., and Bidleman, T. F.: Hexachlorocyclohexanes (HCHs) In the Canadian Archipelago. 2. Air-Water Gas Exchange of a- and g-HCH, Environ. Sci. Technol., 42, 465-470, 2008.

Jaward, F. M., Farrar, N. J., Harner, T., Sweetman, A. J., and Jones, K. C.: Passive Air Sampling of PCBs, PBDEs, and Organochlorine Pesticides Across Europe, Environ. Sci. Technol., 38, 34-41, 2004.

Kaiser, A.: Origin of polluted air masses in the Alps. An overview and first results for MONARPOP, Environ. Poll., 157, 32323237, 2009.

Lei, Y. D. and Wania, F.: Is rain or snow a more efficient scavenger of organic chemicals?, Atmos. Environ., 38, 3557-3571, 2004.

Li, Y. F. and Vijgen, J.: Global Lindane Usage. Annex IV, International $\mathrm{HCH} \&$ Pesticides Association (IHPA), available at: http://www.ihpa.info/index.php (last access: 3 February 2015), 2006

Li, Y.-F., Harner, T., Liu, L., Zhang, Z., Ren, N.-Q., Jia, H., Ma, J., and Sverko, E.: Polychlorinated Biphenyls in Global Air and Surface Soil: Distributions, Air-Soil Exchange, and Fractionation Effects, Environ. Sci. Technol., 44, 2784-2790, 2010.

Liu, W., Chen, D., Liu, X., Zheng, X., Yang, W., Westgate, J. N., and Wania, F.: Transport of Semivolatile Organic Compounds to the Tibetan Plateau: Spatial and Temporal Variation in Air Concentrations in Mountainous Western Sichuan, China, Environ. Sci. Technol., 44, 1559-1565, 2010.

Ma, J., Hung, H., Tian, C., and Kallenborn, R.: Revolatilization of persistent organic pollutants in the Arctic induced by climate change, Nat. Clim. Change, 1, 255-260, 2011.

Mandalakis, M. and Stephanou, E. G.: Wet deposition pf polychlorinated biphenyls in the eastern Mediterranean, Environ. Sci. Technol., 38, 3011-3018, 2004.

Murray, M. W. and Andren, A. W.: Precipitation Scavenging of Polychlorinated Biphenyls Congeners in the Great Lakes Region, Atmos. Environ., 26A, 883-897, 1992.

Nizzetto, L., Lohmann, R., Gioia, R., Dachs, J., and Jones, K. C.: Atlantic Ocean Surface Waters Buffer Declining Atmospheric Concentrations of Persistent Organic Pollutants, Environ. Sci. Technol., 44, 6978-6984, 2010.

Odabasi, M., Cetin, B., Demircioglu, E., and Sofuoglu, A.: Air-water exchange of polychlorinated biphenyls (PCBs) and organochlorine pesticides (OCPs) at a coastal site in Izmir Bay, Turkey, Mar. Chem., 109, 115-129, 2008.

Park, J. S., Wade, T. L., and Sweet, S.: Atmospheric deposition of organochlorine contaminants to Galveston Bay, Texas. Atmos. Environ., 35, 3315-3324, 2001.
Poster, D. L. and Baker, J. E.: Influence of Submicron Particles on Hydrophobic Organic Contaminants in Precipitation. 1. Concentrations and Distributions of Polycyclic Aromatic Hydrocarbons and Polychlorinated Biphenyls in Rainwater, Environ. Sci. Technol., 30, 341-348, 1996.

Potter, T. L., Hapeman, C. J., McConnell, L. L., Harman-Fetcho, J. A., Schmidt, W. F., Rice, C. P., and Schaffer, B.: Endosulfan wet deposition in Southern Florida (USA), Sci. Total Environ., 468-469, 505-513, 2014.

Pozo, K., Urrutia, R., Barra, R., Mariottini, M., Treutler, H. C., Araneda, A., and Focardi, S.: Records of polychlorinated biphenyls (PCBs) in sediments of four remote Chilean Andean Lakes, Chemosphere, 66, 1911-1921, 2007.

Quaghebeur, D., Smet, B. D., Wulf, E. D., and Steurbaut, W.: Pesticides in rainwater in Flanders, Belgium: results from the monitoring program 1997-2001, J. Environ. Monitor., 6, 182-190, 2004.

Schmid, P., Bogdal, C., Blüthgen, N., Anselmetti, F. S., Zwyssig, A., and Hungerbühler, K.: The Missing Piece: Sediment Records in Remote Mountain Lakes Confirm Glaciers Being Secondary Sources of Persistent Organic Pollutants, Environ. Sci. Technol., 45, 203-208, 2011.

Schuster, J. K., Gioia, R., Breivik, K., Steinnes, E., Scheringer, M., and Jones, K. C.: Trends in European Background Air Reflect Reductions in Primary Emissions of PCBs and PBDEs, Environ. Sci. Technol., 44, 6760-6766, 2010.

Shen, L. and Wania, F.: Compilation, Evaluation, and Selection of Physical-Chemical Property Data for Organochlorine Pesticides, J. Chem. Eng. Data, 50, 742-768, 2005.

Su, Y., Wania, F., Harner, T., and Lei, Y. D.: Deposition of polybrominated diphenyl ethers, polychlorinated biphenyls, and polycyclic aromatic hydrocarbons to a boreal deciduous forest, Environ. Sci. Technol., 41, 534-540, 2007.

Sun, P., Basu, I., and Hites, R. A.: Temporal Trends of Polychlorinated Biphenyls in Precipitation and Air at Chicago, Environ Sci. Technol., 40, 1178-1183, 2006a.

Sun, P., Blanchard, P., Brice, K., and Hites, R. A.: Atmospheric organochlorine pesticide concentrations near the Great Lakes: Temporal and spatial trends, Environ. Sci. Technol., 40, 65876593, 2006b.

Taniyasu, S., Kannan, K., Holoubek, I., Ansorgova, A., Horii, Y., Hanari, N., Yamashita, N., and Aldous, K. M.: Isomer-specific analysis of chlorinated biphenyls, naphthalenes and dibenzofurans in Delor: polychlorinated biphenyl preparations from the former Czechoslovakia, Environ. Poll., 126, 169-178, 2003.

Tørseth, K., Aas, W., Breivik, K., Fjæraa, A. M., Fiebig, M., Hjellbrekke, A. G., Lund Myhre, C., Solberg, S., and Yttri, K. E.: Introduction to the European Monitoring and Evaluation Programme (EMEP) and observed atmospheric composition change during 1972-2009, Atmos. Chem. Phys., 12, 5447-5481, doi:10.5194/acp-12-5447-2012, 2012.

Totten, L. A., Gigliotti, C. L., Vanry, D. A., Offenberg, J. H., Nelson, E. D., Dachs, J., Reinfelder, J. R., and Eisenreich, S. J.: Atmospheric Concentrations and Deposition of Polychlorinated Biphenyls to the Hudson River Estuary, Environ. Sci. Technol., 38, 2568-2573, 2004.

UNEP: Final act of the conference of plenipotentiaries on the Stockholm convention on persistent organic pollutants. Document: UNEP/POPS/CONF/4, available at: www.pops.int/documents/ 
meetings/dipcon/meetingdoclist_en.htm (last access: 3 February 2015), 2001.

van Drooge, B. L., Grimalt, J. O., Torres-Garcia, C. J., and Cuevas, E.: Deposition of semi-volatile organochlorine compounds in the free troposphere of the eastern north Atlantic Ocean, Mar. Pollut. Bull., 42, 628-634, 2001.

Wang, P., Zhang, Q., Wang, Y., Wang, T., Li, X., Li, Y., Ding, L., and Jiang, G.: Altitude dependence of polychlorinated biphenyls (PCBs) and polybrominated diphenyl ethers (PBDEs) in surface soil from Tibetan Plateau, China, Chemosphere, 76, 1498-1504, 2009.

Weber, J., Halsall, C. J., Muir, D., Teixeira, C., Small, J., Solomon, K., Hermanson, M., Hung, H., and Bidleman, T.: Endosulfan, a global pesticide: A review of its fate in the environment and occurrence in the Arctic., Sci. Total Environ., 408, 2966-2984, 2010.
Wong, F., Jantunen, L. M., Pucko, M., Papakyriakou, T., Staebler, R. M., Stern, G. A., and Bidleman, T. F.: Air-Water Exchange of Anthropogenic and Natural Organohalogens on International Polar Year (IPY) Expeditions in the Canadian Arctic, Environ. Sci. Technol., 45, 876-881, 2011.

Wong, H. L., Giesy, J. P., and Lam, P. K. S.: Atmospheric deposition and fluxes of organochlorine pesticides and coplanar polychlorinated biphenyls in aquatic environments of Hong Kong, China, Environ. Sci. Technol., 38, 6513-6521, 2004.

Xiao, H., Li, N., and Wania, F.: Compilation, Evaluation, and Selection of Physical-Chemical Property Data for alpha-, beta-, and gamma-Hexachlorocyclohexane, J. Chem. Eng. Data, 49, 173 185, 2004.

Zhang, L., Cheng, I., Muir, D., and Charland, J.-P.: Scavenging ratios of polycyclic aromatic compounds in rain and snow in the Athabasca oil sands region, Atmos. Chem. Phys., 15, 1421-1434, doi:10.5194/acp-15-1421-2015, 2015. 